\title{
Perseroan Terbatas sebagai Institusi Kegiatan Ekonomi yang Demokratis
}

\author{
Johari Santoso
}

\begin{abstract}
The presence of the company limited acts is a concret step from the government in the effort of giving a guide for business people in running their commercial activities and this case it support the Indonesia business people in order to thing progressively. It is aimed that company limited is as an institution of transparancy and efficiency can be achieved by a company limited.
\end{abstract}

\section{Pendahuluan}

Salah satu badan usaha yang relatif dominan dalam kegiatan ekonomi adalah badan usaha berbentuk Perseroan Terbatas (PT). Banyak perusahaan-perusahaan yang sekarang ini merubah status badan hukumnya menjadi Perseroan Terbatas. Faktor yang mendorong terhadap perubahan status bentuk perusahaan dari bentuk lain ${ }^{1}$ menjadi Perseroan Terbatas salah satunya dikarenakan bentuk Perseroan Terbatas adalah sebuah wadah usaha yang melakukan pemisahan hak dan kewajiban para pengusaha bersangkutan selaku pemegang saham dengan hak dan kewajiban perusahaan. Di samping itu dalam Perseroan Terbatas juga dikenal adanya pemisahan harta kekayaan.

Dalam pandangan ini eksistensi Perseroan Terbatas pada hakekatnya merupakan institusi kegiatan ekonomi yang mempunyai fungsi selain menjalankan kegiatan usaha juga sebagai lembaga ekonomi yang demokratis.

Idealisasi dari konsepsi di atas mendorong Perseroan Terbatas dituntut dalam melaksanakan kegiatannya harus didukung oleh kerangka kerja yang jelas dan sumber daya manusia

'Dalam sistem hukum Indonesia dikenal beberapa bentuk perusahaan. Misalnya ada perusahaan perseorangan, perusahaan yang berbadan hukum, perusahaan yang tidak berbadan hukum, serta perusahaan milik negara serta koperasi. Lihat Ridwan Khairandy, et.al. 2000. Pengantar Hukum Dagang Indonesia. Yogyakarta: Pusat Studi Hukum FH UII. HIm 13-92. Lihat Juga Abdul Kadir Muhammad. 1999. Hukum Perusahaan. Bandung: Citra Aditya Bakti. HIm. 45-129. 
yang berkualitas. Adapun máksud dan tujuannya agar lembaga kegiatan Perseroan Terbatas sebagai salah satu unit usahá dan badan hukum di Indonesia dapat dijalänkan secara produktif, berkualitas dan efesien yang diorieritasikan "menjadi lembaga yang demokratis.

Berikut ini akan dideskripsikan tentang Perseroan Terbatas sebagai wadah (institusi) kegiatan ekonomi yang membanidingkannya juga' dengan ketentuan lama di dalam KUHD, sekaligus menguraikan keterkaitannya dengan lembaga ekonomi yang demokratis.

\section{Faktor Pemilihan PT sebagai Bentuk Badan Hukum Usaha}

Istilah Perseroan Terbatas (PT) yang digunakan dewasa ini dulunya dikenal dengan istilah Naamloze Vennootschap (NV). ${ }^{2}$ Bagaimana asal muasal digunakannya istifah Perseroan Terbatas dan disingkat dengan PT tidak dapat ditelusuri, tetapi sebutan tersebut telah menjadi baku di dalam masyarakat bahkan juga dibakukan di dalam. UU No. 1 Tahun 1995 tentang Perseroan Terbatas. ${ }^{3}$

Pengertian Perseroan Terbatas terdiri dari dua kata, yakni perseroan dan terbatas. Perseroan merujuk kepada modal PT yang terdiri dari sero-sero atau saham-saham.
Adapun kata terbatas merujuk kepada pemegang.yang luasnya hanya sebatas pada nilai nominal semua saham yang dimilikinya. 4 - Lebih lengkapnya pengertian 'dari Perseroan Terbatas terdapat pada ketentuan Pasal 1 UUPT bahwa perseroan terbatas yang selanjutnya disebut perseroan adalah, badan hukum yang didirikan berdasarkan perjanjian, melakukan kegiatan usaha dengan modal dasar yang seluruhnya terbagi dalam saham; dan memenuhi persyaratan yang. ditetapkan dalam undang-undang ini serta peraturan pelaksanaannya.

Berdasarkan kepada pengertian yang dijabarkan dalam Pasal 1 UUPT, maka unsurunsur PT meliputi; PT adalah badan hukum, didirikan berdasarkan perjanjian, melakukan kegiatan usaha, modalnya terdiri dari sahamsaham.

Perseroan Terbatas (PT). merupakan perusahaan yang oleh Undang-Undang dinyatakan sebagai perusahaan yang berbadan hukum. Dengan status yang demikian itu, PT menjadi subjek hukum yang menjadi pendukung hak dan kewajiban, sebagai badan hukum, PT memiliki kedudukan mandiri (persona standi in judicio) yang tidak tergantung kepada pemegang sahamnya. PT juga harus organ yang, dapat mewakili PT atau perseroan yang menjalankan

${ }^{2}$ Charles Himawan menyatakan The Code uses instead the term Naamloze Vennootschap, i.e association without a name derived from the French term Societe Anonyme (SA). Although the designation N.V an abbreviation of the Dutch term Naamloze. Vennootschap is still used, the designation PT (for Perseroan terbatas - limited (liability) Company) is now more common. Lihat dalam Charles Himawan. 1973. "Business Law: Contract and Business Associations." Survey of Indonesian Economic Law Padjadjaran University Faculty of Law. Bandung: Lembaga Penelitian Hukum dan Kriminologi FH UNPAD. HIm. 40.

${ }^{3}$ Selanjutnya.UU No. 1 Tahun 1995 dalam tulisan ini disebut UUPT.

${ }^{4}$ H.M.N. Purwosutjipto. 1981. Pengertian Pokok Hukum Dagang Indonesia. Jakarta: Djambatan. HIm. 85. 
perusahaan. ${ }^{5}$ Hal ini berarti PT dapat melakukan perbuatan-perbuatan hukum seperti seorang manusia dan dapat pila mempunyai kekayaan atau utang (ia bertindak dengan perantaraan pengurusnya). ${ }^{6}$

Walaupun suatu badan hukum itu bukanlah seorang manusia yang mempunyai pikiran/kehendak, akan tetapi menurut hukum ia dapat dianggap mempunyai kehendak. Menurut teori yang lazim dianut, kehendak dari persero pengurus dianggap sebagai kehendak PT. Akan tetapi, perbuatanperbuatan pengurus yang bertindak atas nama $P T$, pertanggungjawabannya terletak pada PT dengan semua harta bendanya. ${ }^{7}$

Beberapa pertimbangan mengapa dipilih bentuk Perseroan Terbatas (PT) sebagai bentuk badan hukum usaha dalam melakukan kegiatan bisnis. Menurut Normin S Pakpahan faktor-faktor tersebut antara lain: ${ }^{8}$

1. Kedudukan yang mandiri dari perseroan terbatas-

Perseroan Terbatas oleh hukum dipandang berdiri sendiri otonom terlepas dari orang perorangan yang berada daiam PT tersebut. di satu pihak PT merupakan wadah himpunan orang-orang yang mengadakan kerjasama dalam PT, di lain pihak segala perbuatan yang dilakukan dalam rangka kerjasama dalam PT tersebut, oleh hukum dipandang sematamata sebagai perbuatan badan itu sendiri.

2. Pertanggungjawaban yang terbatas

Pertanggungjawaban dibebankan kepada harta kekayaan yang terhimpun dalam asosiasi. Ini berarti beban resiko (equity) sebagai suatu kegiatan ekonomi terbatas pada kekayan perseroan.

3. Adanya mobilitas atas hak penyertaan Dampak positif dari konstruksi ini adalah terjaganya keutuhan modal yang telah terkumpul, tanpa adanya kemungkinan dimintanya kembali bagiannya yang telah disetor ke perseroan, kecuali bila sekalian pemegang saham setuju membubarkan perseroan.

4. Prinsip pengurus oleh suatu organ

Sebagai suatu modal, perseroan terbatas terdiri dari banyak pemegang saham. Jumlah yang amat banyak dari pemegang saham tersebut tidak mungkin semuanya menjadi pengurus.

5. Persyaratan hukum

Banyak dari hukum positif Indonesia mesyaratkan bahwa kegiatan usaha atau bisnis tertentu harus dilakukan oleh badan hukum Indonesia berbentuk PT.

6. Melalui PT Terbuka

a. Dimungkinkan pengerahan dana masyarakat untuk memperoleh dana bagi kepentingan perkembangan

"Ery Árifudin. "Tanggung Jawab Direksi dalam Pembelian Kembali Saham oleh Perseroan Terbatas." Jurnal Hukum dan Keadilan Vol. 2 No. 1 Oktober 1999. HIm. 24.

${ }^{6}$ C.S.T. Kansil. 1995. Hukum Perusahaan Indonesia (Aspek Hukum dalam Ekonomi). Jakarta: PT Pradnya Paramita. HIm: 23

${ }^{7}$ lbid.

${ }^{8}$ Normin S. Pakpahan. "Perseroan Terbatas Sebagai Instumen Kegiatan Ekonomi." Jurnal Hukum Bisnis Vol. 2/1997. HIm. 75. 
perusahaan:

b. Masyarakat memperoleh kesempatan :untuk ikut serta dalam kegiatan. ekonomi: yang dapat memberikan keuntungàn.

c. Dapat terjadi pemerataan kesejahteraan kepada masyarakat luas melalui kepemilikan dan jual beli saham.

d. Akan meningkatkan tanggung jawab sosial suatu PT dan sekaligus menunjukan PT berada dalam pengamatan dan kontrol masyarakt, baik melalui pemegang saham. ataupun melalui pasar modal.

Meniurut Sri Rejeki Hartono sendiri PT menjadi suatu badan hukum usaha banyak dipilih oleh masyarakat oleh, karena PT. mempunyai nilai-nilai lebih baik ditinjau dari aspek ekonomi sendiri maupun dari aspek yuridisnya. Kedua aspek tersebut adalah saling mengisi satu terhadap yang lain. Sedangkan aspek hukumnya memberikan rambu-rambu pengaman serta mengatur agar keseimbangan kepentingan semua pihak dapat diterapkan dengan sebaik-baiknya dälam rangka menjalankan kegiatan ekonomi. ${ }^{9}$

Selanjutnya ia juga mengemukakan alasan lainnya kenapa masyarakat banyak memilih kegiatan ekonominya menggunakan PT. Secara praktis menurutnya ada beberapa alasan: 10

1. Setiap jenis usaha yang mempunyai, jangkauan relatif luas, pada ijin oprasional selalu menyatakan bahwa perusahaan yang bersangkutan harus berbentuk badan hukum (pilitian utama pasti PT).

2. Setiap jenis usaha yang bergerak di bidang keuangan diisyaratkan dalam bentuk badan hukum, pilihan utama. adalah juga PT.

3. Perusahaan "yang berpeluang" memanfaatkan Bursa Modal hanyalah PT. Dari berbagai pandangan dan alasan pemilihan bentuk badan hukum usaha PT, maka kalau dicermati wajarláh apabila PT selalu menjadi tujuan utama dari masyarakat dalam mengelolola kegiatan usahanya.

\section{Beberapa Pembaharuan di dalam UUPT}

Sejak tanggal 7 Maret 1997 bangsa Indonesia memiliki suatu peraturan baru di bidang hukum persekutuan perniagaan khususnya dalam bidang hukum perseroan terbatas dengan dikeluarkannya UU No. 1 Tahun 1995 tentang Perseroan Terbatas.

UUPT pada dasamya kalau dibandingkan dengan KUHD dilihat dari banyaknya bab dan pasal-pasalnya, maka dapat disimpulkan bahwa UUPT șekarang lebih rinci dan lebih

${ }^{9}$ Sri Rejeki Hartono. "Beberapa Aspek tentang Permodalan pada Perseroan Terbatas." Makalah disampaikan pada Sominar Nasional Menyongsong Berlakunya UU No. 1 Tahun 1995 Tentang PT dan Implikasinya tehadap perkembangan Dunia Usaha DIIndoneșia. Diselenggarakan oleh kerjasama Asosiași Pengajar Hukum Dagang Seluruh Indonesia-Program Pendidikan Notariat UGM-UNDIP. Yogyakarta. 30 September 1995. Him.5.

${ }^{10} / \mathrm{bid}$. 
lengkap. Hal-hal yang dulu belum. diatur di dalam KUHD. Sekarang diatur di dalam UUPT dan hal-hal yang kurang diatur menjadi dilengkapi."

$\mathrm{Di}$ 'samping itu, UUPT mencoba mengakomodasikan fungsi sosial perseroan terbatas tanpa meninggalkan prinsip-prinsip ekonomi secara wajar, hal ini nampak misalnya pada ketentuan yang berkaitan dengan perlindungari terhadap pemegang saham minoritas, kemungkinan karyawan memperoleh saham dan lain sebagainya. ${ }^{12}$

Konsekuensi dari dikeluarkannya UUPT ini telah membawa konsekuensi hukum terutama sékali terhadap pengaturan hukum mengenai Perseroan Terbatas. Di sini dapat dijelaskan beberapa pembaharuan UUPT dibandingkan dengan yang ada' di KUHD.

Beberapa pembaharuan itu yang dikemukakan menyangkut masalah status hukum, berbeda dengan KUHD, secara formal Perseroan Terbatas (PT) menurut UUPT dinyatakan sebagai badan hukum (Pasal 7 ayat (6)). Secara material tidak berbeda dengan ketentuan dalam KUHD, bahwa PT diperlukan sebagai badan hukum semata-mata karena kriteria dan sifatnya. ${ }^{13}$

Status badan hukum mengandung sifat antara lain pertanggungjawaban terbatas dari pemegang saham (Pasal 3 ayat (1)). Namun demikian, berdasarkan UUPT yang baru dalam keadaan tertentu pertanggungjawaban terbatas tersebut dapat diterobos berdasarkan prinsip piercing the corporate veil, sebagaimana ditentukan di dalam Pasal 3 ayat (2), yaitu apabila: (I) persyaratan perseroan sebagai badan hukum belum atau tidak dipenuhi; (ii) pemegang saham yang bersangkutan baik langsung maupun tidak langsung dengan iktikad buruk memanfaatkan

"Sémúla pengaturan PT dalam KUHD hanya terdiri dari 21 pasal saja (Pasal 36 sampai dengan 56(. Tetapi'UUPT menyediakan lebih dari enam kali lipat, yaitu berjumlah semuanya 129 pasal. Namun demikian. sngguhpun pasal-pasal dari UUPT lebih dari 6 kali lipat dari yang terdapat dalam KUHD, tidaklah berarti.bahwa semua pasal yang lain selain dari KUHD adalah merupakan hal-hal yang baru sama sekali. Sebab, banyak juga pasal UUPT yang hanya merupakan penjabaran lebih lanjut dari pasal-pasal dalam.KUHD, atau bahkan hanya. merupakan kodifikasi atas kebiasaan yang memang sudah pernah dipraktikan di bawah KUHD. Hanya beberapa ketentuan saja yang benar-benar baru, kebanyakannya dicontek dari hukum luar negeri, umumnya dari sistem Anglo Saxon. Munir Fuady. 1996. Hukum Bisnis dalam Teori dan Ptaktik Buku Ketiga. Bandung: Citra Aditya Bakti. HIm. 1. Lihat juga Emmy Pangaribuan Simanjuntak. "Interaksi Fungsi Organ PT dan Perlindungan yang Diberikannya Kepa'da Pemegang Saham dan Kreditur Berdasarkan UUPT." Makalah disampaikan pada Seminar Nasional Menyongsong Berlakunya UU No. 1 Tahun 1995 Tentang PT dan Implikasinya tehadap perkembangan Dunia Usaha DI Indonesia. Diselenggarakan oleh kerjasama Asosiasi Pengajar Hukum Dagang Seluruh Indonesia-Program Pendidikan Notariat UGM-UNDIP. Yogyakära. 30 September 1995. him.2.

${ }^{12 B a g i r}$ Manan. "Interaksi Fungsi Organ PT dan Perlindungan yang Diberikan Kepada Pemegang Saham dan Kreditur Menurut UU No. 1 Tahun 1995." Makalah disampaikan pada Seminar Nasional Menyongsong Berlakunya UU No. 1 Tahun 1995 Tentang PT dan Implikasinya tehadap perkembangan Dunia Usaha DI Indonesia. Diselenggarakan oleh kerjasama Asosiasi Pengajar Hukum Dagang Seluruh indonesiaProgram Pendidikan Notariat UGM-UNDIP. Yogyakarta. 30 September 1995.

${ }^{3}$ Normin S. Pakpahan. Op. Cit. HIm. 75. 
perseroan semata-mata. untuk kepentingan pribadi; (iii) pemegang saham yang. bersangkutan terlibat dalam perbuatan. melawan hukum yang dilakukan oleh perseroan, atau; (iv) pemegang saham yang bersangkutan, baik.langsung maupun tidak langsung secara: melawan hukum menggunakan kekayaan perseroan menjadi tidak cukup' untuk melunasi utang perseroan.14

Berdasarkan kepada perubahan status. hukum PT, maka penyimpangan terhadap UUPT berkaitan dengan pertanggungjawaban direksi maupun komisaris yang melakukan penyimpangan terhadap PT semuanya dapat dimintakan. pertanggungjawabannya dihadapan hukum.

Aspek lainnya adalah masalahipendirian PT, pada prinsipnya pendirian PT sama dengan ketentuan Pasal 15 KUHD, perseroan didirikan berdasarkan perjanjian, karena itu harus ada dua orang atau pendiri atau lebih. Perbedaan dengan KUHD antara lain; (I) di dalam UUPT ditegaskan pendiri diwajibkan: mengambil bagian saham PT yang didirikan (Pasal 7 ayat (2)). Kewajiban seperti ini tidak terdapat di dalam KUHD, (ii) PT yang telah memperoleh status badan hukum tetap diwajibkan mempunyai lebih dari satu pemegang saham (Pasal 7 ayat (3)). Kewajiban semacam ini tidak terdapat dalam KUHD, bahkan KUHD tidak melarang dalam hal R.T setelah memperoleh status badan hukum. seluruh sahamnya dimiliki :oleh satu orang. ${ }^{15}$.

Dalam UUPT yang baru pemilikan seluruh saham oleh satu orang hanya dimungkinkan: untuk sementara waktu. Apabila waktu yaing. ditentukan oleh Undang-undang dilampaui, maka tanggung jawab pemegang saham. tunggal tersebut berubah menjadi tanggung. jawab pribadi. Lebih lanjut, sifat ketunggalan dari pemegang saham dapat dijadikan dasar bagi pihak ketiga untuk menuntut pembubaran PT yang bersangkutan. (iii) Kewajiban mendirikan PT berdasarkan perjanjian dan; kewajiban untuk adanya lebih dari satu pemegang saham, tidak diberlakukan bagi pendirian PT Persero. Penegasan pengecualian ini untuk menghindarkan terjadinya penyeludupan hukum yang selama ini dilakukan dalam pendirian persero., ${ }^{16}$

UUPT juga tidak lagi memuat ketentuan yang terkandung dalam Pasal 47 KUHD yang berarti bahwa bubarnya PT tidak dikaitkan lagi dengan kerugian yang dideritanya. Selain itu UUPT yang terdiri dari 129 pasal telah memuat berbagai hal yang diperlukan -untuk pengoperasian usaha dengan bentuk PT: antara lain menyangkut modal dan sàhám; direksi, komisaris, RUPS, Penggabungan, peleburan dan pengambilalihan, pembubaran serta likuidasj. ${ }^{17}$

Bila mencermati UUPT akan terlihat dengan jelas 'bahwa UUPT mengenal istilah PT terbuka yang di dalam KUHD istilah ini tidak dikenal. Dengan adanya PT Terbuka màka

${ }^{14} /$ bid.

15/bid.

${ }^{16} /$ bid.

"I Nyoman Tjager. "Beberapa Catatan Mengenai UUPT," Makalah disampaikan pada Seminar Nasional Menyongsong Berlakunya UU No. 1 Tahun 1995 Tentang PT dan Implikasinya tehadap perkembangan Dunia Usaha DI Indonesia. Diselenggarakan oleh kerjasama Asosiasi Pengajar Hukum Dagang Seluruh Indonesia-Program Pendidikan Notariat UGM-UNDIP. Yogyakarta. 30 September 1995. HIm.1. 
PT tersebut sahamnya dimiliki oleh masyarakat melalui proses go public yang dilakukan berdasarkan UU No. 8 Tahun 1995 teritang Pasar Modal.

Sebenarnya masih banyak hal-hal yang lain yang dapat dikomparasikan antara apa yang ada di dalam ketentuan UUPT dengan KUHD.yang jelas aturan UUPT lebih lengkap kétimbang yang ada di dalam KUHD.

\section{Perseroan Terbatas sebagai Institusi Ekonomi yang Demokratis .}

Setelah mengetahui beberapa kelebihan dari UUPT dibanding dengan KUHD, maka yang tak kalah menariknya adalah adanya ketentuan-ketentuan yang terdapat dalam UUPT berkaitan dengan hubungan antar organ-organ satu sama lain yang dapat dibedakan menjadi dua bentuk hubungan utama. Pertama; hubungan organis. Kedua; hubungan fungsional. Hubungan organis adalah hubungan yang berkaitan dengan keberadaan (eksistensi) organ-organ tersebut: Hubungan fungsional adalah hubungan yang berkaitan dengan pelaksanaan. fungsi masing-masing organ sebagai penetap kebijáksanaan, pelaksanaan kebijaksanaan; pengawasan atas pelaksanaan dan lain-lain. ${ }^{18}$ Olet karena pengaturan PT seperti ini; maka dapatlah dikatakan bahwa PT merupakan institusi kegiatan ekonomi yang bersifät demokratis.

Beberapa Bukti dari kesemuanya itu nampak pada mekanisme Rapat Umum
Pemegang Saham yang merupakan kekuasaan tertinggi dalam pengambilan keputusan di PT yang bukan bagian dari kewenagan direksi dan komisaris pada hakekatnya sebagai bentuk institusi ekonomi yang mengedepankan demokratisasi pengambilan keputusan.

Menurut Pasal 72 UUPT, setiap saham memiliki satu suara kecuali jika ditentukan lain oleh anggaran dasar. Bagi saham perseroan yang dimiliki oleh perseroan itu sendiri tidak mempunyai hak suara. Demikian juga bagi saham induk perusahaan yang dimiliki anak perusahaannya tidak mempunyai hak suara. Keputusan RUPS adalah sah apabila persyaratan penyelenggaraannya telah dipenuhi dan dihadiri oleh para pemegang saham yang ditentukan UUPT dan anggaran dasar perseroan. Mengenai ketentuan kuorum dalam penyelenggaraan RUPS diatur dari Pasal 73 samapai dengan Pasal 76 UUPT. 19

RUPS dapat dilaksanakan apabila dihadiri oleh pemegang saham yang mewakili lebih dari setengah (satu perdua), bagian dari jumlah seluruh saham dengan hak suara yang sah. Keputusan diambil secara musyawarah untuk mufakat tersebut; maka képutusan diambil. berdasarkan suara terbanyak biassa darijumlah suara yang dikeluarkan secara sah. ${ }^{20}$

'. RUPS diberi kedudukan sebagai organ tertinggi oleh UUPT tetapi tidak berarti bahwa RUPS dapat melakukan lingkup tugas dan wewenang yang telah diberikan undangundang dan anggaran dasar kepada direksi dan komisaris. Faham yang mengatakan

\footnotetext{
${ }^{19}$ Bagir Manan.Op.Cit: HIm.3.

${ }^{19 R}$ Ridwan Khairandy, et.al. Op. Cit. HIm. 51.

${ }^{20}$ Ibid.
} 
bahwa RUPS sebagai organ tertinggi mempunyai kekuasaan tertinggi di dalam PT yang dapat mempéngaruhi tugás sehari-hari direksi sudah ditinggalkan oleh negara yang membentuk KUD sendiri. Dalam U'UP.T tugas, kewajiban dan wewenang dari setiap organ termasuk RUPS sudah diatur secara otonom atau mandiri, diberi kebebasan bergerak asal semuanya dilakukan demi tujuan dan kepentingan perseroan. ${ }^{21}$

Di samping yang telah dikemukakan di atas, aspek lainnya yang dapat membuktikan bahwa kelembagaan PT membawa iklim yang demokratis nampak pada persoalan kepemilikan saham. Sebuah PT yang sudah menyatakan dirinya go public berarti PT ini dapat dikatakan saham dari PT ini sudah banyak dimiliki oleh masyarakat. Artinya kepemilikan PT tidak lagi di monopoli sekelompok orang, tetapi menjadi sebaliknya.

\section{Simpulan}

Kehadiran UUPT merupakan langkah kongkrit dari pemerintah dalam upaya memberikan pedoman bagi pelaku-pelaku bisnis dalam menjalankan kegiatan usahanya, dan hal ini mendorong kalangan pengusaha di Indonesia untuk berpikir lebih maju agar dapat memandang bahwa PT sebagai sebuah institusi dalam kegiatan ekonomi yang sifatnya demokratis, sehingga harapan transparansi dan efesiensi dapat dicapai oleh sebuah PT.

\section{Daftar Pustaka}

Arifudin, Ery. " Tanggung Jawab Direksi dalam Pembelian Kembali Saham oleh
Perseroan Terbatas." Jurnal Hukum dan Keadilan Vol. 2 No. 1 Oktober 1999.

Fuady, Münir. 1996. Hukum Bisnis dalam Teori dan Ptaktik Buku Ketiga. Bandung: Citra Aditya Bakti."

Hartono, Sri Rejeki. " Beberapa Aspek tentang Permodalan pada Perseroan Terbatas." Makalah disampaikan pada Seminar Nasional Menyongsong Berlakunya UU No. 1 Tahun 1995 Tentang. PT dan Implikasinya tehadap perkembangan Dunia

- Usaha DI Indonesia. Diselenggarakan oleh kerjasama Asosiasi Pengajar Hukum Dagang Seluruh IndonesiaProgram Pendidikan Notariat UGMUNDIP. Yogyakarta. 30 September 1995.

Himawan, Charles. 1973. "Business Law: Contract and Business Associations." Survey of Indonesian Economic Law Padjadjaran University Faculty of Law. Bandung: Lembaga Penelitian Hukum dan Kriminologi FH UNPAD.

Kansil, C.S.T. 1995. Hukum Perusahaan Indonesia (Aspek Hukum dalam Ekonomi). Jakarta: PT Pradnya Paramita.

Khairandy, Ridwan, et.al. 2000. Pengantar Hukum Dagang Indonesia. Yogyakarta: Pusat Studi Hukum FH UII.

\footnotetext{
${ }^{21}$ Emmy Pangaribuan. Op. Cit. HIm. 32.
} 
Manan, Bagir. "Interaksi Fungsi Organ PT dan Perlindungan yang Diberikan Kepada Pemegang Saham dan Kreditur Menurut UU No. 1 Tahun 1995.". Makalah disampaikan pada Seminar Nasional Menyongsong Berlakunya UU No. 1 Tahun 1995 Tentang PT dan Implikasinya terhadap perkembangan Dunia Usaha DI Indonesia. Diselenggarakan oleh kerjasama Asosiasi Pengajar Hukum Dagang Seluruh Indonesia-Program Pendidikan Notariat UGM-UNDIP. Yogyakarta. 30 September 1995.

Muhammad, Abdul Kadir. 1989. Hukum Perusahaan. Bandung: Citra Aditya Bakti.

Pakpahan, Normin S. "Perseroan Terbatas Sebagai Instumen Kegiatan Ekonomi." Jurnal Hukum Bisnis Vol. 2/1997.

Purwosutjipto, H.M.N. 1981. Pengertian Pokok Hukum Dagang Indonesia. Jakarta: Djambatan.
Simanjuntak, Emmy Pangaribuan. "Interaksi Fungsi Organ PT dan Perlindungan yang Diberikannya Kepada Pemegang Saham dan Kreditur Berdasarkan UUPT." Makalah disampaikan pada Seminar Nasional Menyongsong Berlakunya UU No. 1 Tahun 1995 Tentang PT dan Implikasinya tehadap perkembangan Dunia Usaha DI Indonesia. Diselenggarakan oleh kerjasama Asosiasi Pengajar Hukum Dagang Seluruh IndonesiaProgram Pendidikan Notariat UGMUNDIP. Yogyakarta. 30 September 1995.

Tjager, I Nyoman. "Beberapa Catatan Mengenai UUPT," - Makalah disampaikan pada Seminar Nasional Menyongsong Berlakunya UU No. 1 Tahun 1995 Tentang PT dan Implikasinya terhadap perkembangan Dunia Usaha DI Indonesia. Diselenggarakan oleh kerjasama Asosiasi Pengajar Hukum Dagang Seluruh Indonesia-Program Pendidikan Notariat UGM-UNDIP. Yogyakarta. 30 September 1995. 